\title{
Sentimen Analisis Terkait Lockdown pada Sosial Media Twitter
}

\author{
Muhammad Dwison Alizah¹, Arifin Nugroho², Ummu Radiyah³, Windu Gata ${ }^{4}$ \\ 1,2,3,4Prodi IImu Komputer, STMIK Nusa Mandiri

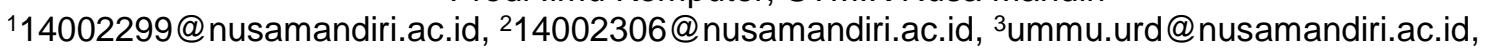 \\ ${ }^{4}$ windu@nusamandiri.ac.id
}

\begin{abstract}
Covid-19 has been set as a Pandemic by the World Health Organization (WHO). The very large impact and the infection that is fast enough are the reasons for making Covid-19 as a pandemic and efforts to overcome. One anticipation that can be done is to do lockdown. Making the decision to carry out a lockdown is intended to reduce the spread that occurs. Lockdown is certainly not a $100 \%$ good solution for all of individual. There are individual who agree that the lockdown will be implemented, also there are those who think that the lockdown is better not to be carried out considering the negative impacts that can occur. Therefore in this study will be presented the predictive modeling for sentiment analysis related to "lockdown" specially on social media Twitter. The method used to labeled was using Vader then the tweets are extracted using TF-IDF, and modeling is made for the prediction of sentiment using Naïve Bayes and Support Vector Machine. The results obtained from the two algorithms are more than $80 \%$.
\end{abstract}

Keywords: Covid-19, lockdown, TF-IDF, Naïve Bayes, Support Vector Machine

Abstrak: Covid-19 telah ditetapkan sebagia Pandemi oleh World Health Organization (WHO). Dampak yang sangat besar dan penyebaran yang cukup cepat menjadi alsan untuk menjadikan Covid-19 sebagai Pandemi dan perlu dilakukan upaya penanggulangan. Salah satu upaya yang bisa dilakukan adalah dengan melakukan lockdown. Pengambilan keputusan untuk melakukan lockdown diperuntukan guna mengurangi penyebaran yang terjadi. Lockdown tentunya bukanlah solusi yang $100 \%$ baik bagi segala pihak. Terdapat pihak - pihak yang menyetujui akan dilaksanakannya lockdown, ada pula yang beranggapan bahwa lockdown lebih baik tidak dilaksanakan dengan pertimbangan dampak negatif yang bisa terjadi. Oleh karena itu, pada penelitian ini akan disampaikan mengenai pembuatan pemodelan prediksi terkait analisa sentimen terkait "Lockdown" yang dikhususkan pada media sosial Twitter. Metode yang digunakan adalah dengan melakukan labeling menggunakan Vader dan selanjutnya tweet tersebut dilakukan ekstraksi menggunakan TF-IDF, dan dibuatkan pemodelan untuk prediksi sentimen menggunakan Naïve Bayes dan Support Vector Machine. Hasil evaluasi yang didapat dari kedua algoritma tersebut ialah mencapai lebih dari $80 \%$.

Kata kunci: Covid-19, lockdown, TF-IDF, Naïve Bayes, Support Vector Machine

\section{A. PENDAhUluan}

Novel coronavirus 2019 (nCoV-2019), atau yang sekarang disebut dengan corona virus disease-19 (COVID-19) sudah ditetapkan sebagai Pandemi oleh World Health Organization (WHO) (Cucinotta \& Vanelli, 2020). Hal ini berakibat banyak negara mulai melakukan "lockdown" untuk mengantisipasi penyebaran virus ini (Lau et al., 2020). Di Indonesia, hal ini belum dilakukan oleh Pemerintah walaupun terdapat beberapa penduduk Indonesia menyuarakan "lockdown" demi menekan penyebaran virus. Tentunya banyak hal yang perlu dipertimbangkan pemerintah tentang dampak dari penerapan "lockdown" bagi Indonesia.

Twitter adalah penyedia layanan pesan yang menyediakan begitu banyak karakteristik dengan alat komunikasi yang digunakan ("Text Mining Dan Sentimen Analisis Twitter Pada Gerakan Lgbt," 2017). Twitter termasuk salah satu media sosial yang ramai digunakan untuk 
berbagi informasi. Salah satu faktornya ialah penggunaannya yang mudah dan mobilitas yang tinggi. Pertukaran informasi pada Twitter termasuk dalam kategori yang sangat cepat. Pengguna bisa berbagi informasi apa saja dan menautkan tagar untuk mempermudah pencarian informasi.

Pengguna Twitter beberapa hari kebelakang banyak sekali yang berbagi informasi mengenai Covid-19 setelah virus ini ditetapkan sebagia Pandemi dan telah masuk di Indonesia. Tidak sedikit pula yang menyuarakan untuk melakukan lockdown melalui Twitter. Hal inilah yang mendorong penelitian ini untuk membuat sebuah pemodelan analisis sentimen terkait dengan tweets mengenai "lockdown" di Indonesia.

Skema lockdown dilakukan di beberapa Negara guna menekan angka penyebaran pandemi Covid-19. Tentunya banyak Pro dan Kontra terkait dengan pemberlakukan skema tersebut. Oleh karena itu, penulis mencoba untuk menganalisa dan membuat pemodelan machine learning terkait dengan analisis sentimen dari tweets "lockdown". Analisis sentimen merupakan suatu proses pengolahan informasi untuk mengelompokan atau mengklasifikasi opini, penilaian seseorang terkait kreasi, organisasi, atau aktivitas tertentu (Buntoro et al., 2019). Tujuan dari melakukan analisa sentimen ialah untuk menentukan perilaku dan opini penulis terhadap topik tertentu (Pramono, Didi Rosiyadi, \& Windu Gata, 2019).

Pemodelan yang akan dilakukan pada penelitian ini menggunakan metode Support Vector Classification dan Naïve-Bayes. Support Vector Machine (SVM) dan Naïve-Bayes merupakan metode yang bisa digunakan baik untuk klasifikasi maupun regresi (Bustami, 2014; Ma \& Guo, 2014), (Frank, Trigg, Holmes, \& Witten, 2000). Beberapa penelitian sebelumnya terkait sentimen analisis pada twitter seperti (Buntoro et al., 2019) dan (Pratama \& Sarno, 2016) menggunakan Support Vector Classification dan Naïve-Bayes dan menghasilkan performa yang baik dan cukup bervariasi. Pada penelitian kali ini, SVM dan Naïve-Bayes digunakan sebagai metode klasifikasi untuk memprediksi label sentimen pada suatu tweets pada twitter.

\section{B. METODE PENELITIAN}

Pada penelitian ini, penulis mencoba menggunakan beberapa metode Natural Language Processing (NLP) dan Machine Learning. Secara umum metodologi yang dilakukan pada penelitian ini mengacu kepada SEMMA Data Mining Process (Azevedo \& Santos, 2008). Tahapan yang dilakukan pada penelitian ini dijelaskan pada Gambar 1.

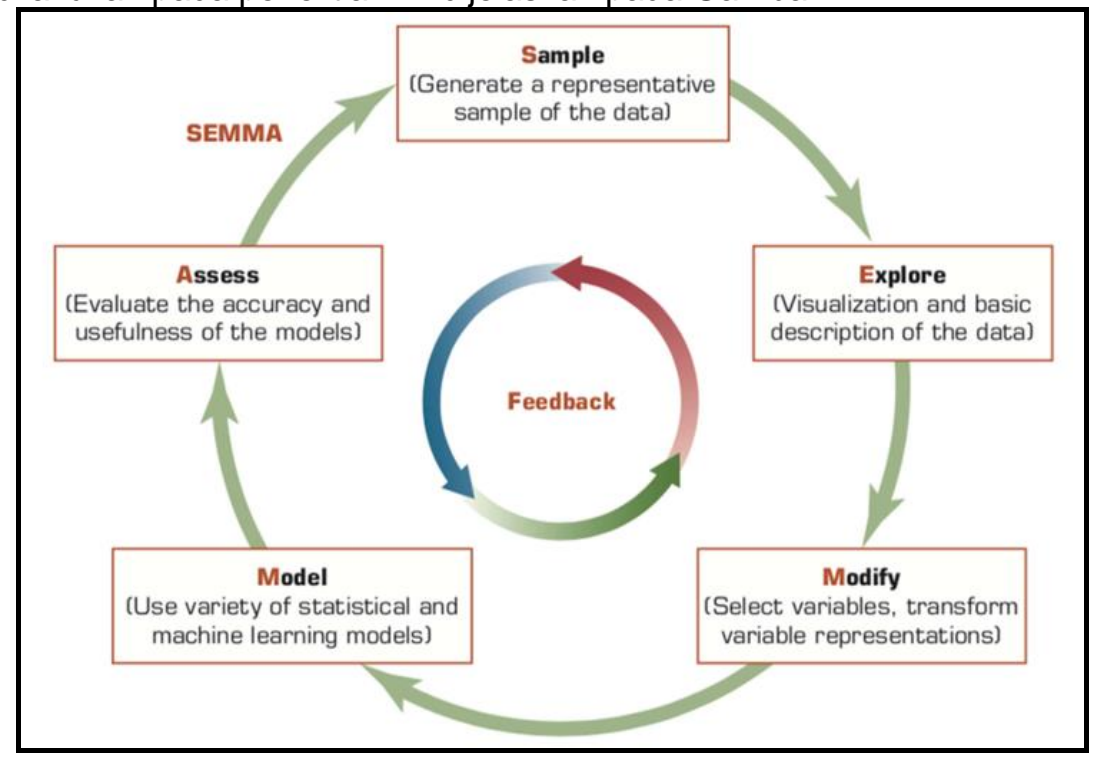

Gambar 1. Semma Data Mining Process (Wardhani, 2015)

\section{Sample}

Pada tahap Pengumpulan Data, dilakukan pengumpulan data terkait tweets "lockdown" pada media sosial twitter memanfaatkan API Twitter. Data yang dikumpulkan disimpan dalam format JSON pada sebuah file. Selanjutnya data tersebut dibaca dan dilakukan proses persiapan data. 


\section{Explore}

Pada tahap ini dijelaskan mengenai deskripsi data dan visualisasi data. Deskripsi data akan menjelaskan mengenai apa gambaran besar dari informasi data yang digunakan. Visualisasi data akan memperlihatkan informasi secara visual dari data.

\section{Modify}

Pada tahap ini dilakukan beberapa metode persiapan data diantaranya:

a. Tokenisasi

Tokenisasi dilakukan untuk memecah sekumpulan kata (kalimat) menjadi kata yang memiliki arti tertentu. Hal ini bertujuan agar kata perkata dapat diolah lebih lanjut dalam proses - proses selanjutnya.

b. Pembersihan URL, Username, Hashtag

Pembersihan ini dilakukan untuk menghilangkan URL atau tautan link website, Username (i.e. @professor.parno), dan Hashtag (\#COVID19) yang ada pada tweets yang ada pada data.

c. Stemming

Stemming merupakan proses yang digunakan untuk mengembalikan kata - kata ke dalam kata dasarnya. Hal ini juga bertujuan untuk membersihkan suatu kata dengan pengeejaan yang kurang tepat.

d. Stopword Removal

Tahap ini merupakan proses untuk melakukan filter terhadap kata - kata umum seperti "the", "a", dan lainnya, yang tidak diperlukan saat pemrosesan data. Kata - kata tersebut dihilangkan dari tweets.

e. Labeling

Tahap ini merupakan tahap dimana hasil dari tahap sebelumnya akan dilakukan perhitungan terhadap polarity dari tweets yang terambil, sehingga dapat menghasilkan label positif maupun negative terkait sentiment dari tweets tersebut.

\section{Model}

Pada tahap ini akan dilakukan proses pembagian data menjadi dua, yaitu data uji dan data latih dengan rasio 3:7. Setelah itu, dilakukan proses ekstraksi fitur dari tweets yang terambil sehingga selanjutnya tweets tersebut dapat dilakukan proses pemodelan machine learning menggunakan data latih untuk melakukan prediksi label pada sentimen tweets pada data uji.

\section{Assess}

Pada tahap ini akan dilakukan evaluasi terhadap pemodelan yang telah dibuat. Evaluasi yang dimaksud adalah membandingkan hasil yang didapat dari model prediksi terhadap data uji dengan label sentimen pada data uji yang sebelumnya sudah diberi label. Hasil evaluasi yang dilakukan dihitung berdasarkan besaran dari precision, recall, f1-score dan akurasi.

\section{HASIL DAN PEMBAHASAN}

Pada bab ini akan dijelaskan mengenai hasil dari penelitan yang dilakukan. Pada percobaan yang dilakukan, penulis menggunakan python sebagai tools dalam menerapkan konsep yang ditawarkan. Hasil dari penelitian ini akan dibagi menjadi beberapa tahapan sesuai dengan metodologi yang digunakan.

\section{Hasil pada tahap Sample.}

Data yang diambil menggunakan Twitter API disimpan ke dalam file. Data yang diambil bersifat mentah dan berisikan keseluruhan atribut yang ada pada tweets di twitter seperti created_at, id, text, source, name, description, hingga retweteeted_status. Atribut yang digunakan nantinya adalah text, dimana data ini merupakan keseluruhan tweet dari data terambil.

\section{Hasil pada tahap Explore.}

Data tweet yang diambil merupakan live tweet pada 19 April 2020 pukul 12:42 sampai dengan 15:02. Tweet yang diambil berdasarkan kata kunci "lockdown" yang menghasilkan 
data sebanyak 15.494 tweet. Pada Tabel 1 ditampilkan tujuh (7) hasil ekstraksi text dari tweets yang terambil.

Tabel 1 Hasil Ekstraksi Text dari Tweets Terambil

\begin{tabular}{|c|c|}
\hline Index & Tweets \\
\hline 0 & RT @ShobhaBJP: Horrific visuals from the land ... \\
\hline 1 & RT @EveningStandard: Lions nap peacefully on S... \\
\hline 2 & $\begin{array}{l}\text { @ImranKhanPTI @MJALSHRIKA This is the \#Hindu } \\
\text { \#... }\end{array}$ \\
\hline 3 & $\begin{array}{l}\text { RT @HLN_BE: Zuid-Korea versoepelt lockdown } \\
\text { bee... }\end{array}$ \\
\hline 4 & I was supposed to have my first cum bukkake ne... \\
\hline 5 & $\begin{array}{l}\text { RT @KChiruTweets: On a Sunday before } \\
\text { lockdown.... }\end{array}$ \\
\hline 6 & RT @tanwer_m: This is from Jehanabad, Bihar. \... \\
\hline
\end{tabular}

\section{Hasil pada Modify}

Tweets yang sudah diambil selanjutnya dilakukan modifikasi untuk nantinya dapat dilakukan proses pembuatan pemodelan machine learning untuk prediksi label sentimen. Pada tahap ini, tweets mentah dilakukan proses tokenisasi, pembersihan, stemming, stopword removal hingga menghasilkan seperti yang ditunjukkan pada tabel 2.

Tabel 2 Hasil Modifikasi Data Tweets

\begin{tabular}{|l|c|c|}
\hline \multicolumn{1}{|c|}{ Tweets } & Compund & Label \\
\hline $\begin{array}{l}\text { rt horrific visuals land } \\
\text { shivajimaharaj hindu ... }\end{array}$ & -0.7964 & negatif \\
\hline $\begin{array}{l}\text { rt lions nap peacefully south } \\
\text { africa roads cor... }\end{array}$ & 0.5267 & positif \\
\hline $\begin{array}{l}\text { hindu sindhi pakistan ready } \\
\text { commit suicide chi... }\end{array}$ & -0.2023 & negatif \\
\hline $\begin{array}{l}\text { rt zuid-korea versoepelt } \\
\text { lockdown beetje }\end{array}$ & 0.0000 & netral \\
\hline $\begin{array}{l}\text { supposed first cum bukkake } \\
\text { next week lockdown ... }\end{array}$ & -0.4767 & negatif \\
\hline $\begin{array}{l}\text { rt sunday lockdown missing } \\
\text { meeting dear ones s... }\end{array}$ & 0.8074 & positif \\
\hline $\begin{array}{l}\text { rt jehanabad bihar kids surging } \\
\text { lockdown eatin... }\end{array}$ & 0.0000 & netral \\
\hline
\end{tabular}

Data yang terlihat pada Tabel 2 menghasilkan data tweets hasil dari proses tokenisasi, pembersihan, stemming, stopword removal dan juga dihasilkan nilai compound yang digunakan sebagai angka untuk melakukan pelabelan pada tweets. 


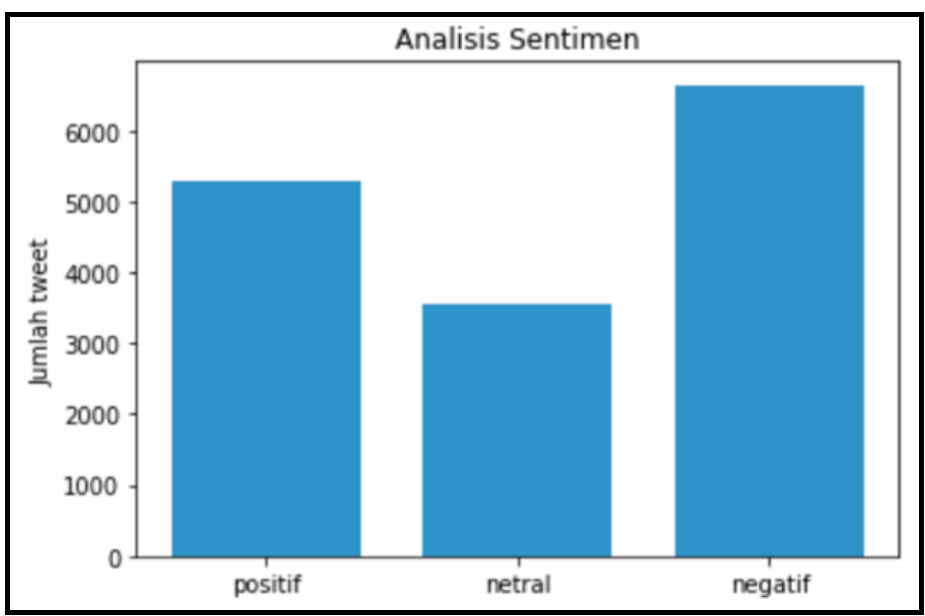

Gambar 2 Histogram dari Jumlah Sentimen (Positif, Netral, dan Negatif)

\section{Hasil pada Proses Model}

Pada tahap ini, data yang siap diproses dibagi menjadi dua bagian, yaitu data latih dan data uji dengan rasio $70 \%$ untuk data latih dan 30\% untuk data uji. Dari total 15.494 data, sebanyak 10.845 dijadikan sebagai data latih, dan 4649 data dijadikan sebagai data uji. Pemodelan machine learning yang digunakan ialah dengan Nä̈ve Bayes dan Support Vector Machine dengan menggunakan metode ekstraksi fitur yaitu Term Frequency-Inverse Document Frequency (TF-IDF).

\section{Hasil pada Proses Assess}

Evaluasi dari pemodelan yang dibuat dijelaskan menggunakan dua metode yaitu Confusion Matrix dan Classification Report. Hasil evaluasi tersebut penulis bagi menjadi dua bagian, yaitu sebagai berikut:

a. Naïve Bayes

Pada Tabel 3 dan tabel 4 berturut-turut adalah hasil evaluasi evaluasi menggunakan Confusion Matrix dan Classification Report pada percobaan menggunakan algoritma Naïve Bayes.

Tabel 3 Confusion Matrix (Naive Bayes)

\begin{tabular}{|l|l|c|c|c|}
\hline & & \multicolumn{3}{|c|}{ Predicted } \\
\hline & & Positif & Netral & Negatif \\
\hline Actual & Positif & 718 & 105 & 247 \\
\cline { 2 - 5 } & Netral & 52 & 1655 & 296 \\
\cline { 2 - 5 } & Negatif & 37 & 142 & 1397 \\
\hline
\end{tabular}

Confusion Matrix pada penerapan Naïve Bayes menunjukan bahwa prediksi benar pada sentiment positif sebanyak 718 , prediksi benar pada netral sebanyak 1655 , dan prediksi benar terhadap sentiment negatif sebanyak 1397.

Tabel 4 Classification Report (Naive Bayes)

\begin{tabular}{|c|c|c|c|c|}
\hline & Precision & Recall & $\begin{array}{l}\text { F1- } \\
\text { score }\end{array}$ & Support \\
\hline Negative & 0.89 & 0.67 & 0.77 & 1070 \\
\hline Netral & 0.87 & 0.83 & 0.79 & 2003 \\
\hline Positif & 0.72 & 0.89 & 0.79 & 1576 \\
\hline Accuracy & & & 0.81 & 4649 \\
\hline Macro avg & 0.83 & 0.79 & 0.80 & 4649 \\
\hline $\begin{array}{l}\text { Weighted } \\
\text { avg }\end{array}$ & 0.82 & 0.81 & 0.81 & 4649 \\
\hline
\end{tabular}

Classification Report pada penerapan Naïve Bayes menunjukan hasil evaluasi seperti precision, recall, f1-score dengan rataan sebesar 0,80 dan 0,81 . . 
IJSE - Indonesian Journal on Software Engineering, Vol.6, No.2, Desember 2020, 223-229 pISSN: 2461-0690 I elSSN: 2714-9935

b. Support Vector Machine

Pada Tabel 5 dan tabel 6 berturut-turut adalah hasil evaluasi menggunakan Confusion Matrix dan Classification Report pada percobaan menggunakan algoritma Support Vector Machine.

Tabel 5 Confusion Matrix (SVM)

\begin{tabular}{|l|l|c|c|c|}
\hline \multicolumn{2}{|c|}{} & & \multicolumn{3}{|c|}{ Predicted } \\
\hline & & Positif & Netral & Negatif \\
\hline \multirow{3}{*}{ Actual } & Positif & 866 & 109 & 95 \\
\cline { 2 - 5 } & Netral & 60 & 1835 & 108 \\
\cline { 2 - 5 } & Negatif & 55 & 164 & 1357 \\
\hline
\end{tabular}

Confusion Matrix pada penerapan SVM menunjukan bahwa prediksi benar pada sentiment positif sebanyak 886 , prediksi benar pada netral sebanyak 1835 , dan prediksi benar terhadap sentiment negatif sebanyak 1357.

Tabel 6 Classification Report (SVM)

\begin{tabular}{|c|c|c|c|c|}
\hline & Precision & Recall & F1-score & Support \\
\hline Negative & 0.88 & 0.81 & 0.84 & 1070 \\
\hline Netral & 0.87 & 0.92 & 0.89 & 2003 \\
\hline Positif & 0.87 & 0.86 & 0.87 & 1576 \\
\hline Accuracy & & & 0.87 & 4649 \\
\hline Macro avg & 0.87 & 0.86 & 0.87 & 4649 \\
\hline Weighted avg & 0.87 & 0.87 & 0.87 & 4649 \\
\hline
\end{tabular}

Classification Report pada penerapan SVM menunjukan hasil evaluasi seperti precision, recall, f1-score dengan rataan sebesar 0,87.

\section{KESIMPULAN DAN SARAN}

Berdasarkan penelitan yang dilakukan, dapat disimpulkan bahwa Naïve Bayes dan Support Vector Machine memiliki performa yang cukup baik untuk memprediksi sentimen dari suatu tweets mengenai lockdown pada media sosial Twitter. Naïve Bayes mampu mencapai akurasi sebesar $81 \%$ dengan f1-score 0.8, sedangkan Support Vector Machine mampu mencapai akurasi sebesar $87 \%$ dengan $f 1$-score 0.87 .

Saran penelitian lanjutan ialah dengan melakukan penelitan menggunakan data yang lebih banyak dan dengan proses persiapan data yang lebih baik. Juga bisa dilakukan dengan mengganti metode yang digunakan, baik saat ekstraksi fitur, maupun saat pembuatan model prediksi

\section{REFERENSI}

Azevedo, A., \& Santos, M. F. (2008). KDD, semma and CRISP-DM: A parallel overview. MCCSIS'08 - IADIS Multi Conference on Computer Science and Information Systems; Proceedings of Informatics 2008 and Data Mining 2008.

Buntoro, G. A., Alvianda, F., Adikara, P. P., Al Kabir, A. H., Yasid, M., Hayuningtyas, R. Y., ... Susanto, A. (2019). Analisis Sentimen Opini Publik Bahasa Indonesia Terhadap Wisata Tmii Menggunakan Naïve Bayes Dan Pso. Jurnal Pengembangan Teknologi Informasi Dan IImu Komputer (J-PTIIK) Universitas Brawijaya, 3(1), 1-10. https://doi.org/10.22219/repositor.v1i1.11

Bustami. (2014). Penerapan Algoritma Naive Bayes. Jurnal Informatika.

Cucinotta, D., \& Vanelli, M. (2020). WHO declares COVID-19 a pandemic. Acta Biomedica. https://doi.org/10.23750/abm.v91i1.9397 
Frank, E., Trigg, L., Holmes, G., \& Witten, I. H. (2000). Naive Bayes for Regression. Machine Learning, 41(1), 5-25. Retrieved from http://www.cs.waikato.ac.nz/ eibe/pubs/nbr.pdf

Lau, H., Khosrawipour, V., Kocbach, P., Mikolajczyk, A., Schubert, J., Bania, J., \& Khosrawipour, T. (2020). The positive impact of lockdown in Wuhan on containing the COVID-19 outbreak in China. Journal of Travel Medicine. https://doi.org/10.1093/jtm/taaa037

Ma, Y., \& Guo, G. (2014). Support vector machines applications. In Support Vector Machines Applications. https://doi.org/10.1007/978-3-319-02300-7

Pramono, F., Didi Rosiyadi, \& Windu Gata. (2019). Integrasi N-gram, Information Gain, Particle Swarm Optimation di Naïve Bayes untuk Optimasi Sentimen Google Classroom. Jurnal RESTI (Rekayasa Sistem Dan Teknologi Informasi), 3(3), 383-388. https://doi.org/10.29207/resti.v3i3.1119

Pratama, B. Y., \& Sarno, R. (2016). Personality classification based on Twitter text using Naive Bayes, KNN and SVM. Proceedings of 2015 International Conference on Data and Software Engineering, ICODSE 2015. https://doi.org/10.1109/ICODSE.2015.7436992

Text Mining Dan Sentimen Analisis Twitter Pada Gerakan Lgbt. (2017). Intuisi : Jurnal Psikologi IImiah, 9(1), 18-25.

Wardhani, P. A. (2015). Business Intelligence, Analytics, and Data Science: A Managerial Perspective. In Efikasi Diri dan Pemahaman Konsep IPA dengan Hasil Belajar IImu Pengetahuan Alam Siswa Sekolah Dasar Negeri Kota Bengkulu (4th ed., Vol. 6). https://doi.org/10.1017/CBO9781107415324.004 